\title{
Styrene Monomer Migration from Expanded Polystyrene Into Food Acids and Ethanol
}

\author{
Paul Dawson ${ }^{1}$, Atif Can Seydim² \& Douglas Hirt ${ }^{3}$ \\ ${ }^{1}$ Food, Nutrition and Packaging Sciences, Clemson University, Clemson, SC 29634-0316, USA \\ ${ }^{2}$ Suleyman Demirel University, Isparta, Turkey \\ ${ }^{3}$ Chemical Engineering, Clemson University, USA \\ Correspondence: Paul Dawson, Food, Nutrition and Packaging Sciences, Clemson University, Clemson, SC \\ 29634-0316, USA. Tel: 1-864-656-1138. E-mail: pdawson@clemson.edu \\ Technical Contribution No. 6822 of the Clemson University Experiment Station
}

Received: April 8, $2020 \quad$ Accepted: April 25, $2020 \quad$ Online Published: May 17, 2020
doi:10.5539/jfr.v9n3p39

\begin{abstract}
Migration of styrene monomer from expanded polystyrene (EPS) at various time intervals (3 hr, 1, 2, 3, 5, 7, 9, 12,18 days at $51^{\circ} \mathrm{C}$ ) into nine different simulants (water, $8 \%$ ethanol in water, $3 \%$ acetic acid, and 3 and $10 \%$ of food-grade citric, malic and tartaric acid) was determined using a modified FDA migration cell. Exposure to $8 \%$ ethanol resulted in the greatest average migration of styrene $(147.6 \mu \mathrm{g} / \mathrm{L})$ during 18 days of storage compared to all other simulants tested. The concentration for styrene in $8 \%$ ethanol ranged from 49.3 to $228.5 \mu \mathrm{g} / \mathrm{L}$ over all exposure times. For all simulants tested, styrene concentrations were greater than or equal to $22 \mu \mathrm{g} / \mathrm{L}$ after 3 hours of exposure. EPS exposed to malic (3 and 10\%) and 10\% tartaric acids had greater styrene migration than styrene exposed to all other acidic simulants tested.
\end{abstract}

Keywords: styrene migration, food simulants, food acids, polystyrene

\section{Introduction}

\subsection{Polystyrene Used in Food Contact}

Polymeric materials (plastic) play a major role in food processing, preservation, marketing, and in the microwave cooking applications. Plastics offer advantages including being relatively inexpensive, versatility in manufacture, lightweight, stable and durable (Achilias, Giannoulis, \& Papageorgiou, 2009). While plastic packaging is popular, the use of plastic materials is not without risk to human health and/or loss of quality to the packaged food. Food products may also encounter a loss in quality due to product-package interaction (migration, scalping and reaction). This concern centers on the migration of low molecular weight compounds in the package such as residual monomers and additives into the food.

\subsection{Styrene Migration Quality and Safety}

The migration of styrene from packaging into food (Jensen, 1972, Davies \& Dunn, 1973, Withey \& Collins, 1978) and uptake by animals (Withey, 1976) have been studied since the 1970s. Polystyrene contains detectable amounts of residual styrene monomer, which is one source of off-flavors in packaged food (Linssen, Janssens, Reitsma, \& Roozen, 1991a). Whereas styrene monomer migration into food products changes sensory quality (Durst \& Laperle, 1990), it also has possible toxicologic and carcinogenic health effects (Loprieno et al., 1976, Arvanitoyannis \& Bosnea, 2004). An increase in the rate of chromosomal aberrations has been observed in humans exposed to styrene (Meretoja, Vainio, Sorsa, \& Härkönen, 1977). Although there is no evidence that styrene is mutagenic, it was found that styrene can be metabolized through a metabolic process into styrene oxide, which is mutagenic in some test systems. Daily styrene exposure is estimated to be between 18.2 and 55.2 ug/person resulting in an annual exposure of 6.7 to $20.2 \mathrm{mg} /$ person (Paraskevopoulou, Achilias, \& Paraskevopoulou, 2011). Styrene can have a toxic effect on the liver and acts as a central nervous system depressant resulting in neurological impairment (Arvanitoyannis \& Bosnea, 2004). The National Institutes of Health's National Toxicology Program (NTP) labeled styrene monomer as "reasonably anticipated to be a human carcinogen" in 2011 (Genualdi, Nyman, \& Begley, 2013). Conversely, Gelbke et al. (2019) concluded that 
styrene migration into food present a low risk for consumers except for food with a high ethanol content. The World Health Organization, Health Canada and US Environmental Protection Agency have established Tolerable Daily Intake levels for styrene, ranging from $7.7 \mathrm{mg} / \mathrm{kg}$ of body weight/day to $200 \mathrm{mg} / \mathrm{kg}$ of body weight/day (WHO, 2003; Health Canada, 1993; US EPA, 1990). The tolerable daily intake for children was set at $1 \mathrm{mg} / \mathrm{kg}$ of body weight/day and the estimated daily intake for Irish children was $0.023 \mathrm{mg} / \mathrm{kg}$ of body weight/day (Duffy and Gibney, 2007). The US FDA permits the use of polystyrene as an indirect additive (food contact) with the condition that there is not more than 1\% (w/w) residual styrene monomer (USFDA CFR, 2019).

\subsection{Styrene Migration Studies}

Tawfik \& Huyghebaert (1997) conducted a comprehensive study of styrene migration of retail packaging in Belgium, Germany and the Netherlands. These researchers sampled 60 polystyrene cups packaged in different foods including: water, milk $(0.5,1.55$ and $3.6 \%$ fat), cold beverages (apple juice, orange juice, carbonated water, cola, beer and chocolate drink), hot beverages (tea, coffee, chocolate and soup (0.0, 0.5, 1, 2, and $3.6 \%$ fat), take away foods (yogurt, jelly, pudding and ice-cream), as well as aqueous food simulants (3\% acetic acid, 15, 50, and $100 \%$ ethanol) and olive oil. Styrene migration was found to be strongly dependent upon the fat content and storage temperature with drinking water having migration values considerably lower than all fatty foods. One hundred \% ethanol had a $0.37 \%$ styrene migration of the total styrene in the cup while $15 \%$ ethanol showed a migration level equivalent to milk or soup containing 3.6\% fat. Maximum observed migration for cold or hot beverages and take-away foods was $0.025 \%$ of the total styrene in the cup. In a separate study out of Australia, Fanjak \& Sharrad (1984) sampled 146 foods packaged in polystyrene including yogurt, cream, cheese, ice cream egg white, onion dip and margarine. These researchers found the highest level of styrene in yogurt at $0.1 \mathrm{mg} / \mathrm{kg}$ with $85 \%$ of the yogurt samples having values less than $0.5 \mathrm{mg} / \mathrm{kg}$. The lowest values were found in margarine with more than $90 \%$ of these samples containing less than $0.01 \mathrm{mg} / \mathrm{kg}$.

In a review of styrene migration studies, Genualdi et al., (2013) reported that styrene monomer concentrations in foods have not significantly changed since the 1980s and monomer concentrations in food packaging quantified were all below USFDA limits. Styrene dimers and trimers are present in higher concentrations in PS food contact materials than the monomer however their migration to food is limited because of their high $K$ values $\left(4 \times 10^{2}\right.$ to $2 \times 10^{6}$ ) and their low diffusion coefficients in PS products. Conversely, Khaksar \& Ghazi-Khansari (2009) reported that the migration of styrene from GPPS (general purpose polystyrene and HIPS (high impact polystyrene) cups to hot drinks was above the EPA (Environmental protection agency) recommended level, especially in MCLG (Maximum contaminant level goal) standard (Table 1).

Table 1. Monomer styrene content in hot beverages exposed to general-purpose polystyrene (GPPS) and high impact polystyrene (HIPS). Adapted from Khaksar \& Ghazi-Khansari, (2009)

\begin{tabular}{lll}
\hline & \multicolumn{2}{l}{ Monomer styrene content $(\mu \mathrm{g} / \mathrm{L})^{3}$} \\
\hline Time & GPPS $^{1}$ & HIPS $^{2}$ \\
\hline Hot tea & $0.61-8.15$ & $0.48-6.85$ \\
Hot milk & $0.65-8.30$ & $0.61-7.65$ \\
Hot chocolate milk & $0.71-8.65$ & $0.72-7.78$ \\
\hline
\end{tabular}

${ }^{1} \mathrm{GPPS}=$ general-purpose polystyrene. ${ }^{2} \mathrm{HIPS}=$ high impact polystyrene.

${ }^{3}$ Data were compiled from 162 samples of each hot beverage content using high performance liquid chromatography

Like other studies, styrene monomer migration from polystyrene disposable into hot and fat-containing beverages was greater with higher fat content and higher temperature. Ehret-Henry, J., Ducruet, Luciani, \& Feigenbaum (1994) also used HPLC to measure styrene migration into yogurt, cream and chocolate desserts and found migration was less than $5 \mathrm{ug} / \mathrm{kg}(\mu \mathrm{g} / \mathrm{L})$.

Choi, Jitsunari, Asakawa, \& Lee, (2007) investigated temperature effects on migration with polystyrene in two-sided contact with $n$-heptane and distilled water as food simulants at temperatures of 10, 24 and 40, and 40, 60 and $90^{\circ} \mathrm{C}$. Heptane fully extracted the styrene monomer and the oligomers from the polystyrene sheet, whereas in the distilled water only styrene trimer migration could be detected. Based on Fick's Law, the apparent diffusion coefficient followed an increased migration due to temperature and the higher the molecular weight of the oligomers, the more significant the reduction in the diffusion coefficient. The diffusion coefficient of the trimers was also higher for heptane contact than for water. Lin, Song, Fang, Wu, \& Wang (2017) compared the migration of virgin and recycled EPS using the same methodology as with the current study (gas 
chromatography-mass spectrometry) in two-sided contact with isooctane at 25 and $40^{\circ} \mathrm{C}$ and found recycled EPS gave greater migration ratios than virgin EPS, indicating that styrene and ethylbenzene migrated more easily from recycled EPS. O'Neill \& Tuohy, (1994) compared food simulants of $0.15,50$ and $100 \%$ ethanol to $0.5,3.5$ and $10 \%$ fat milk and found that styrene monomer migration into 3.5\% milk correlated most closely with the 50\% ethanol simulant. While there is significant database published for styrene migration from solid polystyrene into food or food simulating liquids, less information is available concerning the migration of styrene from foamed polystyrene into aqueous acidic solutions. The purpose of this study was to determine the effect of acid concentration on the migration of styrene from foam polystyrene cups (EPS).

\section{Methods}

\subsection{Materials and Sample Preparation}

Two packs of polystyrene foam (EPS) cups (Solo®, Dart Container Company, Michigan) with an internal cup volume of $251.4 \mathrm{ml}(8.5 \mathrm{oz}$.) and 51 cups of each pack were purchased from the local supermarket. After receiving, the samples were placed in Zip-Lock ${ }^{\circledR}$ bags (First Brand Corporation. Danbury, CT, 06813) and stored in a freezer until the initiation of the experiment. Nine different aqueous food simulants were used for testing; distilled/deionized water $\left(\mathrm{ddH}_{2} \mathrm{O}\right)$ (Barnstead Ultrapure Water System Barnstead Corporation. Dubuque, IA), $8 \%$ ethanol in water, 3\% acetic acid (Mallinckrodt, Paris, KY 40361), 3\% and 10\% solutions of food-grade citric acid (ADM, Decatur, IL 62525), malic acid (Spectrum, Gardena, CA 90248), tartaric acid (ADM, Decatur, IL 62525). Beer and wine generally range from 3 to $11 \%$ alcohol while fruit juices range from $<1.0$ to $>8.0 \%$ acid so the alcohol and acid levels chosen for testing were in the range of these types of foods.

\subsection{Migration Cell}

The migration cell (Figure 1) (Till et al., 1982 b) was modified to test styrene migration from EPS into aqueous food simulants. Cups were taken from frozen storage immediately before each analysis. Circular discs were cut from the cup wall with cork corer (\#6) to an average diameter and thickness of $1.18 \mathrm{~cm}$ and $0.23 \mathrm{~cm}$, respectively. Five discs were carefully stacked on a stainless-steel wire with glass beads $(3.5 \mathrm{~mm}$ diameter) used as spacers, then placed in a $22 \mathrm{ml}$ headspace vial (Tekmar Corp., Cincinnati, OH 45249) and filled with $10 \mathrm{ml}$ of the desired test simulant. Each sample vial was crimped with Teflon ${ }^{\circledR}$ faced silicon-rubber septa (Thelco Model 130DM, Precision Scientific, Chicago, IL 60610).

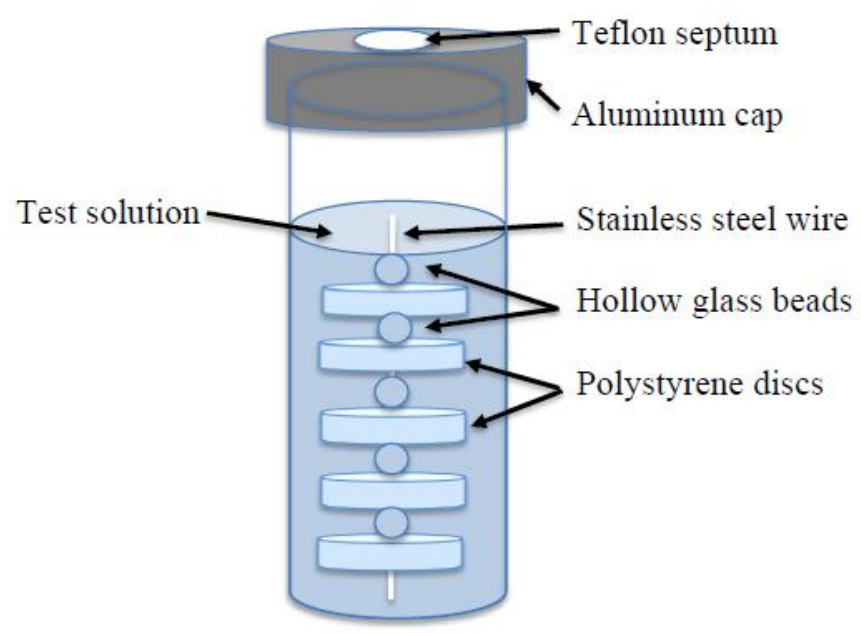

Figure 1. Drawing of the modified migration cell used for detection of styrene monomer from polystyrene using headspace gas chromatographic analysis

\subsection{Test Conditions}

The migration cells were incubated in a laboratory oven at $51^{\circ} \mathrm{C} \pm 2^{\circ} \mathrm{C}$ without agitation. Samples were removed from the oven after 3 hours ( 0 day), 1, 2, 3, 5, 7, 9, 12, 15 and 18 days, vigorously shaken using a vortex and then analyzed for styrene content. Three hours was the minimum exposure time since all samples achieved the equilibration temperature $\left(51^{\circ} \mathrm{C} \pm 2^{\circ} \mathrm{C}\right)$ after this time period. Three replicate samples from 3 different migration cells were analyzed for each storage time and treatment. The FDA recommendation for time and temperature of migration studies is "Sponsors should conduct migration testing under the most severe conditions of temperature and time anticipated for the proposed use," this includes $40^{\circ} \mathrm{C}$ for 10 days room temperature applications which 
was previously recommended to be $49^{\circ} \mathrm{C}$ (FDA, 2007). The European Union Directive 82/711/EEC recommendations for contact temperature ranged from $5^{\circ} \mathrm{C}$ to $175^{\circ} \mathrm{C}$ depending upon the food simulant being tested. More specifically conventional test conditions recommendation were either at 40 or $60^{\circ} \mathrm{C}$ (Simmons, 2009). The temperature used in the current study $\left(51^{\circ} \mathrm{C} \pm 2^{\circ} \mathrm{C}\right)$ fell within the range of the USFDA and EU guidelines while exposure times were much longer. The objective in the current study was to determine if differences existed between food acids in styrene migration thus the researchers believe longer exposure times were valid.

Residual (initial) styrene monomer concentration in the polystyrene discs was determined by dissolving 0.1 grams of EPS cup in $2 \mathrm{ml}$ of N, N-dimethylacetamide (J.T. Baker, Pillsburg, NJ 08865) followed by an injection of $5 \mu \mathrm{l}$ into a sealed empty headspace vial.

\subsection{Styrene Analysis}

Prepared migration cells were heated at $91^{\circ} \mathrm{C}$ for 30 minutes using a headspace autosampler (HP Model 5890 Series II Gas Chromatograph, Hewlett Packard Corp., Wilmington, DE 19808) that was interfaced to a gas chromatograph (DB-5, J\&W Scientific, Folsom, CA 95630). Then, a sample of headspace from each vial was automatically injected onto the head of a $30 \mathrm{~m}$ fused silica capillary column $(0.32$ i.d. $\times 30 \times 1 \mu \mathrm{m})$ maintained at $40^{\circ} \mathrm{C}$. The column was temperature programmed from $40^{\circ} \mathrm{C}$ to $90^{\circ} \mathrm{C}$ at $5^{\circ} \mathrm{C} / \mathrm{min}$ and from $90^{\circ} \mathrm{C}$ to $190^{\circ} \mathrm{C}$ at $15^{\circ} \mathrm{C} / \mathrm{min}$ with the helium (flow of $30 \mathrm{ml} / \mathrm{min}$ ) as the carrier gas. The flame ionization detector signals were stored and integrated using a computer software program (DB-5, J\&W Scientific, Folsom, CA 95630).

Peak identification for volatiles was based on the retention times of authentic reference standards. Peak identification was also verified by manual injection of the headspace onto a gas chromatograph equipped with a mass spectrometric detector (Saturn II 3400 GC/MS equipped with 8100 autosampler, Varian Corp., Sugar Land, TX 77478). A representative sample was allowed to equilibrate for 30 minutes in a sealed headspace vial partially submerged in a water bath $\left(90^{\circ} \mathrm{C}\right)$, then a $1 \mathrm{ml}$ aliquot of the headspace gas was transferred to the $\mathrm{GC}$ column using heated gas-tight syringe (Precision Sampling Corp., Baton Rouge, LA 70895). A 0.32mm (i.d.) $\times$ $30 \mathrm{~m} \times 0.25 \mu \mathrm{m}$ fused silica column DB-5, J \& W Scientific, Folsom, CA 95630) was used for separation with the identical chromatographic conditions described previously in this section. A full-range of mass selective detection was run in the ion-trap mode, monitoring $\mathrm{m} / \mathrm{z} 104$ for styrene or for one of the following associated products of styrene; o-xylene (1,2-diethylbenzene) (m/z 106), m-xylene (1,3-dimethylbenzene) $(\mathrm{m} / \mathrm{z} 106)$ and $\beta$-D-styrene ( $\mathrm{m} / \mathrm{z}$ 105). Integration of the peaks was performed using a computer (Compaq DeskPro II, Compaq Computer Corp., Houston, TX, 77070) and spectra were matched with the Wiley5 Mass Spectral Registry Library. The GC/MS analysis was for verification of peak identification only and not used in quantitation calculations.

Quantitation of styrene in the experimental samples was accomplished from a standard curve prepared by spiking aliquots of pure simulants with styrene monomer (Aldrich, Milwaukee, WI 53233) and analyzed as described previously.

\subsection{Preparation of Standards}

The solubility of styrene was reported as $0.02 \%(200 \mathrm{ppm})$ at room temperature (Brighton, Pritchard, \& Skinner, 1979), therefore, three sets of stock standard solution were prepared by injecting $30 \mu 1$ styrene in $15 \mathrm{ml}$ of water (20ppm), $20 \mu \mathrm{l}$ styrene in $10 \mathrm{ml}$ water (20ppm) and $10 \mu \mathrm{l}$ styrene in $10 \mathrm{ml}$ water (10ppm) respectively, in three headspace vials. Vials then wrapped with aluminum foil to protect from the light and stored in the refrigerator until preparing the working standard solutions. Working standard solutions were prepared by serial dilution with $\mathrm{ddH}_{2} \mathrm{O}$ to prepare from $25 \mu \mathrm{g} / \mathrm{L}$ to $1000 \mu \mathrm{g} / \mathrm{L}$ styrene test solutions. Since the partitioning in the headspace is uniform for all aqueous simulants (Varner \& Breder, 1981a), the same standard curve was used for each simulant.

\subsection{Reporting Results}

Styrene migration into food and food simulants has been reported using different units including mass per mass of food simulant, $\mu \mathrm{g} / \mathrm{L}$ and mass per surface area of styrene. Since the surface area was identical for all of our samples and the comparison between types of simulants was our objective in the current study, the results are expressed both as $\mu \mathrm{g} / \mathrm{L}$ in the food simulant and based on the surface of styrene to simulant volume ratio (S/V). The styrene/surface area is reported as the quantity of styrene migrated per unit area $\left(\mathrm{ng} / \mathrm{cm}^{2}\right)$. Surface area of each cylinder was calculated using equation (1):

$$
\mathrm{A}=2 \pi \mathrm{rh}+2 \pi \mathrm{r}^{2}
$$

where $\mathrm{A}$ is the area of contact with the test solvent, $\mathrm{r}$ is the radius of $1 \mathrm{disc}$, and $\mathrm{h}$ is the disc height. Using this 
formula and the dimensions of one disc $(0.59 \mathrm{~cm}$ radius and $0.23 \mathrm{~cm}$ height $)$, the surface area of one disc was $3.04 \mathrm{~cm}^{2}$, thus the total area of surface contact was 5 times that or $15.20 \mathrm{~cm}^{2}$. To convert $\mu \mathrm{g} / \mathrm{L}$ to $\mathrm{ng} / \mathrm{cm}^{2}$ units, $\mu \mathrm{g} / \mathrm{L}$ were expressed as $\mathrm{ng} / 10 \mathrm{ml}$, which was the total volume of simulant exposed to styrene surfaces. This value was divided by the total surface area to express the results as $\mathrm{mg}$ styrene in the simulant per square $\mathrm{cm}$ of surface area exposed to the simulant. For example, the styrene concentration for 3\% acetic acid after 3 hours of exposure to styrene was $28.1 \mu \mathrm{g} / \mathrm{L}$. This is $28100 \mathrm{ng} / \mathrm{l}$ or $281 \mathrm{ng} / 10 \mathrm{ml}$. by dividing this by the total surface area $\left(281 \mathrm{ng} / 15.20 \mathrm{~cm}^{2}\right)$ gives a styrene concentration based on surface area exposure of $18.5 \mathrm{ng} / \mathrm{cm}^{2}$. This way of reporting data may be useful for comparing different packaging that varies in exposure of food styrene surface areas.

\subsection{Diffusion Rate Calculation}

Crank and Park (1968) described the mathematical derivation of Fick's diffusion laws. The rate of the diffusion process is related to the concentration gradient between the two phases in contact. This is known as Fick's first law and mathematically described in the following equation (2):

$$
q=-D \frac{\delta C}{\delta x}
$$

where $\mathrm{q}$ is the flux, the rate per unit area; $\mathrm{C}$ is the local concentration of the diffusing molecules; $\mathrm{x}$ is the coordinate measured in the direction of diffusion; D is the diffusion coefficient and $(\delta \mathrm{C} / \delta \mathrm{x})$ is the concentration gradient.

The diffusion of a substance within the polymer, where the diffusion occurs only in the $\mathrm{x}$ direction, is described by Fick's second law (3):

$$
\frac{\delta C}{\delta t}=D \frac{\delta^{2} C}{\delta x^{2}}
$$

where $t$ is time.

The rate of diffusion per unit area is equal to a constant (diffusion coefficient) multiplied by the rate of change in concentration of the diffusing substances (Briston \& Katan, 1974; Miltz, \& Mannheim 1987).

Koros \& Hopfenberg (1979) noted that the simplest model for the diffusion process can be observed when there is no interaction between food or food simulants and package which was supported by numerous other studies (Reid, Sidman, Schwope, \& Till, 1980, Till et al.,1982a, Till et al. 1987, Chang, Guttman, Sanchez, \& Smith, 1988, Lickly, Markham, \& McDonald, 1993, Murphy, MacDonald, \& Lickly, 1992, Lehr et al. 1993, Pugh 1994, Castle, Honeybone, Jickells, Philo, \& Sharman, 1994, Lickly, Breder, \& Rainey, 1995). Lickly, Lehr, \& Welsh, (1995b) pointed out that in order to follow Fickian diffusion model, certain criteria should be assumed:

1. There is no resistance to mass transfer of the migrant between the polymer surface and the food or food simulant.

2. There is no penetration of the food packaging by the food or food simulant.

3. The migrant is homogeneously distributed in the polymer material.

4. There is no equilibrium partitioning limiting the migration (well-mixed media).

5. The packaging material was not depleted of the migrant during the experiment.

In addition, Reid et al. (1980) explained that if the polymeric material to be tested is infinitely thick for the concentration of the residual monomer at the mid-plane, less than $50 \%$ migration remains at its original value throughout the experiment, then, the following equation can be used to estimate the amount of migration for infinite and semi-infinite media:

$$
\mathrm{M}_{\mathrm{t}}=2 \mathrm{C}_{\mathrm{po}} \sqrt{\left(\mathrm{D}_{\mathrm{p}} \mathrm{t} / \pi\right)}
$$

where $M_{t}$ is the mass transfer from the surface of the polymer in time $t\left(\mu \mathrm{g} / \mathrm{cm}^{2}\right), C_{p o}$ is the initial residual level in the polymer $\left(\mu \mathrm{g} / \mathrm{cm}^{3}\right), D_{p}$ is the diffusion coefficient $\left(\mathrm{cm}^{2} / \mathrm{s}\right), t$ is the time of exposure in seconds. This equation was used to determine $\mathrm{D}_{\mathrm{p}}$ for styrene in each solvent.

\subsection{Statistical Analysis}

Data from the nine simulant treatments (TMT) of three replicates at ten different storage times (DAY) were analyzed using SAS (Statistical Analysis Software Institute, Cary, NC 27513). General linear model (GLM) 
procedure and randomized complete block design were used to determine the significance of treatments, storage time and their interaction (TMT*DAY). Then, where significance was detected means were separated using the PDIFF command of SAS $(\mathrm{P}<0.05)$.

\section{Results}

\subsection{Overall Styrene Migration}

There were significant effects due to simulant treatments $(p \leq 0.0001)$, replications $(p=0.026)$, storage time $(\mathrm{p} \leq 0.0001)$, and due to simulant treatment by storage time interaction $(\mathrm{p}=0.001)$ on styrene migration. The pooled means over all storage times revealed four groups of simulants with differences $(p \leq 0.05)$ in styrene concentration $(\mu \mathrm{g} / \mathrm{L}$ ) (Figure 2). Exposure to $8 \%$ ethanol solution resulted in the greatest average concentration $147.6 \mu \mathrm{g} / \mathrm{L}$ of styrene with all other acid and water simulants averaging under $60 \mu \mathrm{g} / \mathrm{L}$. Expanded polystyrene styrene exposed to malic acid ( 3 and $10 \%$ ) and $10 \%$ tartaric acid resulted in higher styrene migration compared to water and all other acid types and concentrations tested. In addition, EPS exposure to water, $3 \%$ acidic acid and $10 \%$ citric acid resulted in higher styrene concentrations than $3 \%$ tartaric and citric acid.

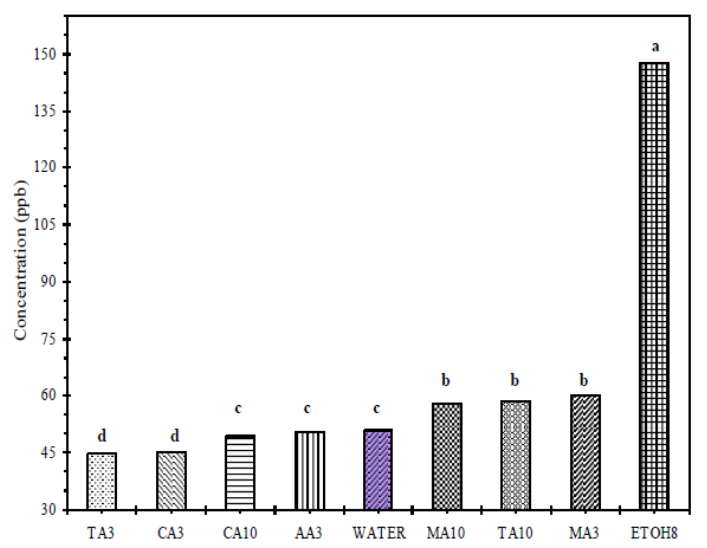

Figure 2. Effect of simulant (solution) on styrene migration from EPS

a, b, c, d, Pooled means* with different superscripts are significantly different $(\mathrm{P}<0.05) \mathrm{n}=3$.

* TA3 (3\% Tartaric Acid); CA3 (3\% Citric Acid); CA10 (10\% Citric Acid);

AA3 (3\% Acetic Acid); MA10 (10\% Malic Acid); TA10(10\% Tartaric Acid);

MA3 (3\% Malic Acid); ETOH8 (8\% Ethanol)

\subsection{Styrene Migration over Time}

When migration was broken down over the 18-day exposure, the higher migration into ethanol compared ranged from $49.3 \mu \mathrm{g} / \mathrm{L}$ (3 hours) to $228.51 \mu \mathrm{g} / \mathrm{L}$ (18 days) (Table 2 ).

Eight $\%$ ethanol had greater styrene monomer migration on each day of sampling compared to all other simulants and none of the organic acids differed from distilled water in styrene migration until 5 days of polystyrene contact.

Initial (3 hours exposure) values were not different $22.5(10 \%)$ and $29 \mu \mathrm{g} / \mathrm{L}(3 \%)$, however, peak values were different after 12 days exposure with $76.2 \mu \mathrm{g} / \mathrm{L}(10 \%)$ and $57.0 \mu \mathrm{g} / \mathrm{L}(3 \%)$. The $10 \%$ levels of tartaric and malic acid did not differ in styrene migration after 18 days, but both were greater than the 18-day styrene values found for $10 \%$ citric acid. It is also interesting to note that water had greater styrene migration than $3 \%$ citric acid and $3 \%$ tartaric acid. Based on these results, weak acids may result in variation in styrene migration. 
Table 2. Styrene monomer (surface area $=15.20 \mathrm{~cm}^{2}$ ) detected in different aqueous simulants $(\mu \mathrm{g} / \mathrm{L}$ ) over 18 days of exposure at $51^{\circ} \mathrm{C}$

\begin{tabular}{llllllllll}
\hline & & \multicolumn{7}{c}{$\mu \mathrm{g} / \mathrm{L}$} \\
\hline time & Acetic & Citric & Citric & Malic & Malic & Tartaric & Tartaric & water & Ethanol \\
& $3 \%$ & $10 \%$ & $3 \%$ & $10 \%$ & $3 \%$ & $10 \%$ & $3 \%$ & & $8 \%$ \\
\hline $3 \mathrm{~h}$ & $28.1^{\mathrm{b}^{*}}$ & $24.7^{\mathrm{b}}$ & $23.0^{\mathrm{b}}$ & $29.3^{\mathrm{b}}$ & $27.9^{\mathrm{b}}$ & $22.6^{\mathrm{b}}$ & $29.1^{\mathrm{b}}$ & $30.1^{\mathrm{b}}$ & $49.3^{\mathrm{a}}$ \\
$1 \mathrm{~d}$ & $34.5^{\mathrm{b}}$ & $37.8^{\mathrm{b}}$ & $35.0^{\mathrm{b}}$ & $37.7^{\mathrm{b}}$ & $38.6^{\mathrm{b}}$ & $37.5^{\mathrm{b}}$ & $38.4^{\mathrm{b}}$ & $41.0^{\mathrm{b}}$ & $58.8^{\mathrm{a}}$ \\
$2 \mathrm{~d}$ & $35.6^{\mathrm{b}}$ & $43.1^{\mathrm{b}}$ & $42.9^{\mathrm{b}}$ & $45.0^{\mathrm{b}}$ & $52.5^{\mathrm{b}}$ & $47.4^{\mathrm{b}}$ & $41.4^{\mathrm{b}}$ & $45.6^{\mathrm{b}}$ & $102.5^{\mathrm{a}}$ \\
$3 \mathrm{~d}$ & $45.6^{\mathrm{b}}$ & $38.5^{\mathrm{b}}$ & $47.1^{\mathrm{b}}$ & $49.0^{\mathrm{b}}$ & $56.1^{\mathrm{b}}$ & $52.9^{\mathrm{b}}$ & $41.8^{\mathrm{b}}$ & $39.8^{\mathrm{b}}$ & $112.5^{\mathrm{a}}$ \\
$5 \mathrm{~d}$ & $49.9^{\mathrm{bc}}$ & $50.6^{\mathrm{bc}}$ & $50.0^{\mathrm{bc}}$ & $58.2^{\mathrm{b}}$ & $62.8^{\mathrm{b}}$ & $61.7^{\mathrm{b}}$ & $41.3^{\mathrm{c}}$ & $52.2^{\mathrm{bc}}$ & $149.2^{\mathrm{a}}$ \\
$7 \mathrm{~d}$ & $59.0^{\mathrm{b}}$ & $57.1^{\mathrm{b}}$ & $49.3^{\mathrm{c}}$ & $60.0^{\mathrm{b}}$ & $66.0^{\mathrm{b}}$ & $67.7^{\mathrm{b}}$ & $49.3^{\mathrm{c}}$ & $53.2^{\mathrm{bc}}$ & $203.6^{\mathrm{a}}$ \\
$9 \mathrm{~d}$ & $57.0^{\mathrm{bc}}$ & $58.5^{\mathrm{bc}}$ & $50.5^{\mathrm{c}}$ & $65.8^{\mathrm{b}}$ & $69.5^{\mathrm{b}}$ & $75.1^{\mathrm{b}}$ & $50.2^{\mathrm{c}}$ & $57.2^{\mathrm{bc}}$ & $197.7^{\mathrm{a}}$ \\
$12 \mathrm{~d}$ & $67.6^{\mathrm{bc}}$ & $58.1^{\mathrm{c}}$ & $50.3^{\mathrm{c}}$ & $75.0^{\mathrm{b}}$ & $73.8^{\mathrm{b}}$ & $76.2^{\mathrm{b}}$ & $57.0^{\mathrm{c}}$ & $61.2^{\mathrm{c}}$ & $204.3^{\mathrm{a}}$ \\
$15 \mathrm{~d}$ & $66.4^{\mathrm{bc}}$ & $61.8^{\mathrm{bc}}$ & $52.1^{\mathrm{c}}$ & $80.0^{\mathrm{b}}$ & $76.1^{\mathrm{b}}$ & $68.1^{\mathrm{b}}$ & $49.7^{\mathrm{c}}$ & $62.0^{\mathrm{bc}}$ & $199.5^{\mathrm{a}}$ \\
$18 \mathrm{~d}$ & $70.4^{\mathrm{bc}}$ & $63.9^{\mathrm{c}}$ & $52.4^{\mathrm{d}}$ & $78.7^{\mathrm{b}}$ & $77.3^{\mathrm{b}}$ & $76.1^{\mathrm{b}}$ & $47.7^{\mathrm{d}}$ & $67.7^{\mathrm{c}}$ & $228.5^{\mathrm{a}}$ \\
\hline
\end{tabular}

${ }^{\mathrm{a}-\mathrm{c}}$ Means within rows with different superscripts are significantly different $(\mathrm{p} \leq 0.05)$.

\subsection{Migration Based On the Estimated Contact Area}

Based on the dimensions of the polystyrene discs used in the study the surface area of contact was calculated to be $15.20 \mathrm{~cm}^{2}$ as described in the methods section. Given the dimensions of a small polystyrene cup as $4.45 \mathrm{~cm}$ and $2.66 \mathrm{~cm}$ diameter for the bottom and top of the cup respectively, and the height of the cup as $11.18 \mathrm{~cm}$, the surfaces area of the cup sides were calculated as $251.5 \mathrm{~cm}^{2}$ and the surface area of the bottom of the cup calculated a $22.23 \mathrm{~cm}^{2}$.

Using the formula for the surface area of the curved portion of the cup by (5):

$$
\pi * h\left(r_{1}+r_{2}\right)
$$

where $\mathrm{h}=$ cup height, $\mathrm{r}_{1}=$ the diameter at the top of the cup and $\mathrm{r}_{2}=$ the diameter at the bottom of the cup. The surface area of the cup bottom was calculated by: $\pi\left(\mathrm{r}_{2}\right)^{2}$. Total surface area a fluid could be exposed to in a small polystyrene cup would be approximately $273.74 \mathrm{~cm}^{2}$. The projected migration of styrene from a small polystyrene cup based on the results from the present study are shown in Table 3. The styrene migrating into the organic acids did not differ from the migration into water except for being lower than that for $10 \%$ tartaric, $10 \%$ malic acid and 3\% malic acid on day 12 .

In the present study, values in excess of $25 \mu \mathrm{g} / \mathrm{L}$ migrated after 3 hours into $3 \%$ and $10 \%$ malic acid. These levels of malic acid are much higher than those found naturally in apples however, the small cup surface area is greater and the projected values of styrene migration from small cups is about 520 times higher than the values from our simulation cell (Table 3). Furthermore, styrene migration continued to increase to greater than 400 $1390 \mu \mathrm{g} / \mathrm{L}$ in both $3 \%$ and $10 \%$ malic acid during the 18 days of storage for the predicted migration in small polystyrene cups.

Table 3. Styrene monomer migration predicted in different aqueous simulants exposed to a small polystyrene cup (surface area $=273.7 \mathrm{~cm}^{2}$ ) over 18 days at $51^{\circ} \mathrm{C}$

\begin{tabular}{llllllllll}
\hline & & \multicolumn{7}{c}{$\mu \mathrm{g} / \mathrm{L}$} \\
\cline { 3 - 9 } time & Acetic & Citric & Citric & Malic & Malic & Tartaric & Tartaric & water & Ethanol \\
& $3 \%$ & $10 \%$ & $3 \%$ & $10 \%$ & $3 \%$ & $10 \%$ & $3 \%$ & & $8 \%$ \\
\hline 3h & 505.8 & 444.3 & 414.3 & 527.1 & 501.9 & 406.6 & 524.9 & 550.3 & 887.9 \\
1d & 621.8 & 680.7 & 629.8 & 679.2 & 694.9 & 675.1 & 690.9 & 737.5 & 1058.9 \\
2d & 640.8 & 777.4 & 771.2 & 810.4 & 945.2 & 853.9 & 745.0 & 820.4 & 1845.2 \\
3d & 821.4 & 692.8 & 848.5 & 878.2 & 1009.7 & 952.6 & 752.2 & 716.3 & 2026.0 \\
$5 \mathrm{~d}$ & 898.0 & 911.1 & 893.1 & 1048.7 & 1131.7 & 1110.7 & 743.2 & 940.9 & 2686.9 \\
$7 \mathrm{~d}$ & 1062.0 & 1028.7 & 887.0 & 1079.6 & 1188.8 & 1219.2 & 888.1 & 958.5 & 3666.9 \\
$9 \mathrm{~d}$ & 1025.0 & 1053.2 & 908.7 & 1185.3 & 1251.0 & 1351.7 & 903.6 & 1029.5 & 3560.5 \\
$12 \mathrm{~d}$ & 1218.1 & 1046.6 & 905.5 & 1349.8 & 1329.1 & 1372.7 & 1025.8 & 1102.4 & 3679.0 \\
$15 \mathrm{~d}$ & 1016.5 & 1112.8 & 938.8 & 1440.5 & 1369.9 & 1226.1 & 895.2 & 1117.3 & 3593.0 \\
$18 \mathrm{~d}$ & 1267.7 & 1150.2 & 944.5 & 1416.5 & 1392.9 & 1370.3 & 858.9 & 1219.8 & 4115.3 \\
\hline
\end{tabular}


Based on the total surface area for 5 polystyrene discs of $15.20 \mathrm{~cm}^{2}$ in the simulation cell then calculating potential migration if food simulants were exposed to a small polystyrene cup with a surface area of $273.74 \mathrm{~cm}^{2}$.

\subsection{Diffusion Coefficients}

Diffusion coefficients for styrene from polystyrene foam into oil during 1 to 10 days exposure ranged from $2.5 \mathrm{x}$ $10^{-9}$ (foam plate) to $8.8 \times 10^{-11}$ (foam cup) (Lickly et al., 1995b) which were in the same range for those found in the present study (Table 4). Paraskevopoulou, Achilias \& Paraskevopoulou (2011) reported diffusion coefficients for polystyrene of $9.8 \times 10^{-11}$ at $25^{\circ} \mathrm{C}$ to $3.8 \times 10^{-12}$ at $60^{\circ} \mathrm{C}$ which also fall in the range of diffusion coefficients in the current study conducted at $51^{\circ} \mathrm{C}$. The migration data from the present study indicated that migration of styrene monomer from the EPS followed the Class II migration. The amount styrene migrating into $3 \%$ citric acid and water reached equilibrium in 5 days while the 3\% levels of tartaric and acetic acid and $10 \%$ citric acid attained equilibrium in 7 days. In addition, the styrene migrated into 3 and 10\% malic acid reached equilibrium between 9 and 12 days. During 18 days of storage, styrene migration into $8 \%$ ethanol increased linearly.

Table 4. The Diffusion Coefficients of Styrene Monomer Migrated into Aqueous Food Simulants $\left(\mathrm{cm}^{2} / \mathrm{s}\right)$

\begin{tabular}{llllllllll}
\hline \multirow{2}{*}{ time } & Acetic & Citric & Citric & Malic & Malic & Tartaric & Tartaric & water & Ethanol \\
& $3 \%$ & $10 \%$ & $3 \%$ & $10 \%$ & $3 \%$ & $10 \%$ & $3 \%$ & & $8 \%$ \\
\hline $3 \mathrm{~h}$ & $1.28 \mathrm{E}-11^{*}$ & $9.96 \mathrm{E}-12$ & $8.66 \mathrm{E}-12$ & $1.39 \mathrm{E}-11$ & $1.27 \mathrm{E}-11$ & $8.28 \mathrm{E}-12$ & $1.38 \mathrm{E}-11$ & $1.52 \mathrm{E}-11$ & $3.96 \mathrm{E}-11$ \\
$1 \mathrm{~d}$ & $2.41 \mathrm{E}-12$ & $2.9 \mathrm{E}-12$ & $2.48 \mathrm{E}-12$ & $2.9 \mathrm{E}-12$ & $3.03 \mathrm{E}-12$ & $2.85 \mathrm{E}-12$ & $2.98 \mathrm{E}-12$ & $3.41 \mathrm{E}-12$ & $7.04 \mathrm{E}-12$ \\
$2 \mathrm{~d}$ & $1.29 \mathrm{E}-12$ & $1.89 \mathrm{E}-12$ & $1.86 \mathrm{E}-12$ & $2.06 \mathrm{E}-12$ & $2.8 \mathrm{E}-12$ & $2.29 \mathrm{E}-12$ & $1.73 \mathrm{E}-12$ & $2.1 \mathrm{E}-12$ & $1.07 \mathrm{E}-11$ \\
$3 \mathrm{~d}$ & $1.41 \mathrm{E}-12$ & $1 \mathrm{E}-12$ & $1.51 \mathrm{E}-12$ & $1.61 \mathrm{E}-12$ & $2.13 \mathrm{E}-12$ & $1.89 \mathrm{E}-12$ & $1.18 \mathrm{E}-12$ & $1.07 \mathrm{E}-12$ & $8.58 \mathrm{E}-12$ \\
$5 \mathrm{~d}$ & $1.01 \mathrm{E}-12$ & $1.04 \mathrm{E}-12$ & $1.0 \mathrm{E}-12$ & $1.38 \mathrm{E}-12$ & $1.61 \mathrm{E}-12$ & $1.55 \mathrm{E}-12$ & $6.93 \mathrm{E}-13$ & $1.11 \mathrm{E}-12$ & $9.04 \mathrm{E}-12$ \\
$7 \mathrm{~d}$ & $1.01 \mathrm{E}-12$ & $9.49 \mathrm{E}-13$ & $7.06 \mathrm{E}-13$ & $1.05 \mathrm{E}-12$ & $1.27 \mathrm{E}-12$ & $1.33 \mathrm{E}-12$ & $7.06 \mathrm{E}-13$ & $8.21 \mathrm{E}-13$ & $1.2 \mathrm{E}-11$ \\
$9 \mathrm{~d}$ & $7.3 \mathrm{E}-13$ & $7.73 \mathrm{E}-13$ & $5.76 \mathrm{E}-13$ & $9.8 \mathrm{E}-13$ & $1.09 \mathrm{E}-12$ & $1.27 \mathrm{E}-12$ & $5.68 \mathrm{E}-13$ & $7.38 \mathrm{E}-13$ & $6.35 \mathrm{E}-12$ \\
$12 \mathrm{~d}$ & $7.73 \mathrm{E}-13$ & $5.73 \mathrm{E}-13$ & $4.29 \mathrm{E}-13$ & $9.5 \mathrm{E}-13$ & $9.21 \mathrm{E}-13$ & $9.84 \mathrm{E}-13$ & $5.51 \mathrm{E}-13$ & $6.34 \mathrm{E}-13$ & $7.07 \mathrm{E}-12$ \\
$15 \mathrm{~d}$ & $4.33 \mathrm{E}-13$ & $5.19 \mathrm{E}-13$ & $3.69 \mathrm{E}-13$ & $8.65 \mathrm{E}-13$ & $7.84 \mathrm{E}-13$ & $6.27 \mathrm{E}-13$ & $3.34 \mathrm{E}-13$ & $5.21 \mathrm{E}-13$ & $5.39 \mathrm{E}-12$ \\
$18 \mathrm{~d}$ & $5.59 \mathrm{E}-13$ & $4.61 \mathrm{E}-13$ & $3.11 \mathrm{E}-13$ & $6.97 \mathrm{E}-13$ & $6.77 \mathrm{E}-13$ & $6.53 \mathrm{E}-13$ & $2.56 \mathrm{E}-13$ & $5.18 \mathrm{E}-13$ & $5.9 \mathrm{E}-12$ \\
ave & $1.07 \mathrm{E}-12$ & $1.12 \mathrm{E}-12$ & $1.03 \mathrm{E}-12$ & $1.39 \mathrm{E}-12$ & $1.59 \mathrm{E}-12$ & $1.49 \mathrm{E}-12$ & $1.00 \mathrm{E}-12$ & $1.21 \mathrm{E}-12$ & $8.01 \mathrm{E}-12$ \\
\hline \multicolumn{2}{r}{$*$}
\end{tabular}

* where;

$\mathrm{M}_{\mathrm{t}}=2 \mathrm{C}_{\mathrm{po}} \sqrt{\left(\mathrm{D}_{\mathrm{p}} \mathrm{t} / \pi\right)}$

$\mathrm{M}_{\mathrm{t}}=0.0206\left(\mu \mathrm{g} / \mathrm{cm}^{2}\right), \mathrm{C}_{\mathrm{po}}=40.11\left(\mu \mathrm{g} / \mathrm{cm}^{3}\right), \mathrm{t}=86400 \mathrm{~s}$ then, $\mathrm{D}_{\mathrm{p}}=2.41 \mathrm{E}-12\left(\mathrm{~cm}^{2} / \mathrm{s}\right)$

\section{Discussion}

The discrepancies in some migration values (8\% ethanol in 5-9 days, $10 \%$ tartaric acid in 12-18 days, $10 \%$ citric acid in 2-5 days, $3 \%$ acetic acid in 9-15 days and 3\% tartaric acid in 12-18 days) would result in inconsistencies with the assumptions previously stated by Reid et al. (1980), Till et al. (1982a), Till et al. (1987), Lickly et al. (1991), Murphy et al. (1992), Lehr et al. (1993), Pugh (1994), Lickly et al. (1995a) and Lickly et al. (1995b). These discrepancies include: (1) lack of resistance to mass transfer of the migrant between the polymer surface and the food or food simulant; (2) no penetration by the food or food simulant into the food packaging; (3) the migrant is homogeneously distributed in the polymer material; (4) no partitioning equilibrium limiting the migration; and (5) the packaging material was not depleted of the migrant into the simulant during the experiment.

Higher rates of styrene migration for $8 \%$ ethanol were also reported compared to other liquid simulants (Till et al., 1982b; Snyder \& Breder, 1985; Varner \& Breder, 1981). The greater styrene migration into 8\% ethanol is not surprising due to the greater degree of solubility of styrene in ethanol. The final amount of styrene migration into 8\% ethanol was over three times that of water. Paraskevopoulou, Achilias and Paraskevopoulou (2011) reported from 0.897 to $1.49 \mathrm{mg} / \mathrm{g}$ migration of styrene into $75 \%$ ethanol held 30 days at 25,40 or $60^{\circ} \mathrm{C}$. These values are several $\log$ values higher than the values from the current study that used $8 \%$ ethanol after exposure for 18 days which may be understandable given the high ethanol concentration and longer exposure time used in the Paraskevopoulou study. In the same study these researchers did not detect styrene migration into water until after 14 days for samples held at $60^{\circ} \mathrm{C}$ and the minimum levels of styrene appear to be higher than other reports thus migration in the $\mu \mathrm{g} / \mathrm{L}$ range were reported as not detectable.

Khaksar and Ghazi-Khansari (2009) reported 7.8, 8.3 and $8.7 \mu \mathrm{g} / \mathrm{L}$ styrene migration into milk, cocoa and tea, 
respectively at $100^{\circ} \mathrm{C}$ after 1 hour of exposure which are approximately 10 times less than the values obtained in the current study after 3 hours of contact.

In addition, the values reported in the current study reflect a range of 28.4 ( 0 day) to 70.1. (18 days) $\mu \mathrm{g} / \mathrm{L}$ styrene migration. Varner \& Breder (1981b) reported 32.0-38.0 $\mu \mathrm{g} / \mathrm{cm}^{2}$ styrene migration into $8 \%$ ethanol after 24 hours exposure at $49^{\circ} \mathrm{C}$. In fact, in the present study after one-day exposure, $34.5 \mu \mathrm{g} / \mathrm{L}$ of styrene was detected in $8 \%$ ethanol $\left(51^{\circ} \mathrm{C} \pm 2^{\circ}\right)$. However, when water was the simulant 30.1 (0 day) to 67.7 (18 days) and 41.0 (1 day) $\mu \mathrm{g} / \mathrm{L}$ styrene was detected $\left(51^{\circ} \mathrm{C} \pm 2^{\circ}\right)$, while Varner \& Breder $(1981 \mathrm{~b})$ found $7.7 \mu \mathrm{g} / \mathrm{cm}^{2}$ styrene was detected by simulating hot filling. These researchers found identical styrene migration values for boiling tea and coffee poured into EPS cups after cooling to $38^{\circ} \mathrm{C}$ at room temperature (1.25 hours). The difference in methodology (i.e. hot filling vs. constant exposure at $51^{\circ} \mathrm{C} \pm 2^{\circ}$ ) could account for the different styrene migration values for water from the present study compared to those found by Varner \& Breder (1981b).

This brings to light the significance of the units used to report styrene migration. As stated earlier, reporting based on surface area may be useful to predict migration in different size containers or packages. Residual styrene monomer will both vary between EPS samples and affect migration values. Varner \& Breder (1981b) reported an average residual of $70.8 \mu \mathrm{g} / \mathrm{L}$ compared to $40.1 \mu \mathrm{g} / \mathrm{L}$ styrene monomer for the present study. Linssen, Janssens, Reitsma, Bredie, \& Roozen (1993) reported that the average threshold level of styrene for yogurts with 3\% fat was $171 \mu \mathrm{g} / \mathrm{L}$. Linssen, Legger-Huysman, \& Roozen (1990) also determined a threshold concentration of $22 \mu \mathrm{g} / \mathrm{L}$ styrene for water. Malic acid is the primary acid in apples (Binnig \& Possmann, 1993), cherries, cranberries, and is also contained in bananas, grapes and pears (Sadler, 1993). Durst \& Laperle (1990) found that panelist detected a styrene monomer flavor difference in apple juice spiked with $25 \mu \mathrm{g} / \mathrm{L}$ styrene.

For acetic acid, Khaksar \& Khansari (2009) reported $88 \mu \mathrm{g} / \mathrm{L}$ of styrene in 3\% acetic acid after 24-hour exposure to polystyrene cups having $120 \mathrm{~cm}^{2}$ surface area while in the current study found $79.2 \mu \mathrm{g} / \mathrm{L}$ when the $34.5 \mu \mathrm{g} / \mathrm{L}$ for $52.27 \mathrm{~cm}^{2}$ was converted to $120 \mathrm{~cm}^{2}$ surface area. For all simulants tested styrene concentrations were 22 $\mu \mathrm{g} / \mathrm{L}$ or greater after 3 hours exposure in the migration cell with $52.27 \mathrm{~cm}^{2}$ EPS surface area.

Foods containing citric acid (citrus fruits, tomatoes, pineapples, raspberries, strawberries and peaches) range in acid levels from $0.2 \%$ (tomatoes) to $8.33 \%$ (lemons) (Sadler, 1993). Citric acid displayed migration ranging from $23.0 \mu \mathrm{g} / \mathrm{L}(3 \%)$ and $24.7 \mu \mathrm{g} / \mathrm{L}(10 \%)$ after three hours to $52.41(3 \%)$ and $63.9 \mu \mathrm{g} / \mathrm{L}(10 \%)$ after 18 days exposure. Gilbert \& Startin (1983) detected 17, 47, $35 \mu \mathrm{g} / \mathrm{L}$ styrene in cold lemon drink, orange drink and lime drink, respectively, in polystyrene cups from retail dispensers (30 min. contacting time). Although exact acid concentrations in these samples was not reported, these drinks typically have acid levels from $<1 \%$ to $2 \%$ (Tressler \& Woodroof, 1976) based on the previous threshold levels reported (Durst \& Laperle, 1990), the values detected in the present study in the range of human sensory detection. Sensory changes were detected in citrus juices stored in polyethylene-laminated aseptic packaging after 14 days (Mannheim, Miltz, \& Letzter, 1987; Mannheim, Miltz, \& Passy, 1988).

Till et al. (1987) reported that the rate of migration is controlled by the diffusion of the migrant within the polymer and the external phase is a sink for any migrant lost. Since diffusional processes in polymers are notably slow (at least several orders of magnitude below those in liquids) the rate-controlling physical step in migration is the diffusion of the substance from the interior of the polymer to the surface. Crank \& Park (1968); Briston \& Katan (1974) also recorded that the external phase is not a passive sink, but penetrates the polymer and modifies the local environment to increase the mobility of the migrant and it may also influence the rate of loss.

The relative solubility of the migrant in the polymer and the external phase and relative volumes of each are important parameters in interpreting migration data. As the external phase approaches its equilibrium migrant concentration, the rate of migration approaches zero. Till et al. (1987) explained if a large excess of external phase were used, then equilibrium saturation effects would be less likely. Therefore, Miltz \& Rosen-Doody (1984) pointed out that an increase in the simulant volume would intensify the driving force for migration of styrene migration. Thus, this would prevent the formation of an equilibrium partitioning (the styrene content in the external phase until it reached an equilibrium with the styrene in the polystyrene). Lickly (1996) also supported that the increase in the simulant volume may change the equilibrium formation in the external phase.

To test this theory, the surface to volume ratio was increased by exposing the EPS samples to higher volumes of simulants. In the present study this ratio was $1.52 \mathrm{~cm}^{2} / \mathrm{cm}^{3}$. There was a linear relationship found between the square root of time and styrene migration except for 3\% citric acid and 3\% tartaric acid.

The migration of styrene from EPS samples followed the concept of Fick's diffusion theory because the total migration increased with the contact time and was proportional to the square root of time at a given exposure temperature. This result was in agreement with other researchers (Reid et al., 1980; Till et al., 1982a; Till et al., 
1982b; Snyder \& Breder, 1985; Till et al., 1987; Durst \& Laperle, 1990; Murphy et al., 1992; Philo et al., 1994; Pugh, 1994; Lickly, Markham, \& McDonald, (1993). Lickly et al., 1995a; Lickly et al., 1995b). However, Reid et al. (1980), Till et al. (1982a), Till et al. (1982b), Till et al. (1987) considered that the migration of styrene into $3 \%$ acetic acid, $8 \%$ ethanol and water is strongly affected by the partitioning equilibrium at an exposure temperature of $40^{\circ} \mathrm{C}$. The exposure surface to volume ratio in these studies ranged from 2.1 to $3.5\left(\mathrm{~cm}^{2} / \mathrm{cm}^{3}\right)$, and accordingly the linear relationship is not observed for these simulants. The different exposure temperatures along with the higher surface area to simulant volume ratio can explain the difference in these results compared to those from the present study. Davies (1974) supported this conclusion finding that an increased surface to volume ratio would eliminate the equilibrium partitioning.

\subsection{Conclusions}

In the current study, the migration of styrene monomer from EPS cups into nine different aqueous food simulants (water, 8\% ethanol, 3\% acetic acid, and 3 and 10\% solutions of food-grade citric, malic, and tartaric acid) was determined using a migration cell. The migration of styrene from EPS into all food simulants tested followed Fickian behavior. Exposure to $8 \%$ ethanol solution resulted in higher migration values than acidic solutions tested. The final amount of styrene migration into $8 \%$ ethanol was over 3 times that of water. The effect of acid type and acid concentration on the migration of styrene from EPS packaging was observed. The $10 \%$ levels of tartaric and malic acid and 3\% malic acid did not differ in styrene migration after 18 days, but all three were greater than the 18-day styrene values found for $10 \%$ citric acid, water, $3 \%$ levels of acetic, citric and tartaric acid. Styrene migration was greater for water than for 3\% citric acid and 3\% tartaric acid. The amount of styrene migrated into food simulants reached an equilibrium point in 5 to 12 days for all simulants tested except for $8 \%$ ethanol. During the storage period, styrene migration into $8 \%$ ethanol increased linearly. During the storage time, the total migration increased with the contact time, and was found to be proportional to the square root of time at the given exposure temperature. The minimum detection limit for styrene with this method was found to be approximately $5 \mu \mathrm{g} / \mathrm{L}$. Exposure to a higher temperature in the headspace autosampler increased the sensitivity of the method compared to other studies. In addition, the increase in the simulant volume changed the formation of partitioning due to the increase in solubility in the external phase.

In addition to toxic effects on the liver and neurological effects at high levels of exposure, lower migrations levels can result in negative sensory impacts. Science-based safe exposure levels based on health protection criteria (animal and human toxicity) were reported to be $90-120 \mathrm{mg} /$ person/day and assuming the consumption of $1 \mathrm{~kg}$ of food/day for adults, this would set the limit of styrene migration at $90 \mathrm{mg} / \mathrm{kg}$ of food or $90 \mathrm{ppm}$ (Gelbke et al., 2013). Since the maximum estimated styrene intake is in the $\mu \mathrm{g} / \mathrm{day}$ range and the safe exposure levels are in the $\mathrm{mg} /$ day range, the health risk from consuming food exposed to styrene packaging is minimal. However, Durst \& Laperle (1990) reported $50 \mu \mathrm{g} / \mathrm{L}$ of styrene in apple juice was detected as a taint, the projected levels of styrene migration into food acids found in this study $(\sim 406-527 \mu \mathrm{g} / \mathrm{L}$ for $3 \%$ acid after 3 hours $)$ would be detectable by humans. Therefore, packaging and exposing different acid types to EPS would have minimal to no health-risk but would likely affect the sensory quality of certain fruit and vegetable juices.

\section{Acknowledgments}

Technical Contribution No. 6822 of the Clemson University Experiment Station. This material is based upon work supported by the NIFA/USDA, under project number SC-1700535.

\section{References}

Achilias, D. S., Giannoulis, A., \& Papageorgiou, G. Z. (2009). Recycling of polymers from plastic packaging materials using the dissolution/reprecipitation technique. Polymer Bulletin, 63(3), 449-465. https://doi.org/10.1007/s00289-009-0104-5

Arvanitoyannis, I. S., \& Bosneea, L. (2004) Migration of substances from food packaging materials to foods. Critical Reviews in Food Science and Nutrition, 44, 63-76. https://doi.org/10.1080/10408690490424621

Binnig, R., \& Possmann, P. (1993). Apple Juice. In S. Nagy, C. S. Chen \& P. E. Shaw (Eds.), Fruit juice processing technology (pp. 271-317). Agscience Inc., FL.

Brighton, C. A., Pritchard, G., \& Skinner, G. A. (1979). Styrene polymers: Technology and environmental aspects. Applied Science Publishers, London. p. 166-196.

Briston, J. H., \& Katan, L. L. (1974). Plastics in contact with food. Food Trade Press, London. p. 129-179.

Castle, L., Honeybone, C. A., Jickells, S. M., Philo, M. R., \& Sharman, M. (1994). Practical aspects of testing food contact materials for migration. Food Addit. Contam., 11(2), 177-185. 
https://doi.org/10.1080/02652039409374217

Chang, S-S., Guttman, C. M., Sanchez, C. I., \& Smith, L. (1988). Theoretical and computational aspects of migration of package components to foods. In J. H. Hotchkiss (Ed.), Food and Package Interactions (pp. 106-117). ACS Series 365. https://doi.org/10.1021/bk-1988-0365.ch009

Choi, J. O. K., Jitsunari, F., Asakawa, F., \& Lee, D. S. (2007). Migration of styrene monomer, dimers and trimers from polystyrene to food simulants. Food Additives and Contaminants, 22(7), 693-699. https://doi.org/10.1080/02652030500160050

Crank, J., \& Park, G. S. (1968). Diffusion in polymers. Academic Press, NY. p. 45-104.

Davies, J. T., \& Dunn, J. W. (1973). Detection and estimation of styrene monomer in food packaged in polystyrene containers. Proc. Inst. Food Sci. Tech., 6, 84-85.

Davies, J. T. (1974). Migration of styrene monomer from packaging material into food. Experimental verification of a theoretical model. J. Food Tech., 9, 275-283. https://doi.org/10.1111/j.1365-2621.1974.tb01774.x

Durst, G. L., \& Laperle, E. A. (1990). Styrene monomer migration as monitored by purge and trap gas chromatography and sensory analysis for polystyrene containers. J. Food Sci., 55(2), 522-524. https://doi.org/10.1111/j.1365-2621.1990.tb06800.x

Duffy, E., \& Gibney, M. J. (2007). Use of a food-consumption database with packaging information to estimate exposure to food-packaging migrants: expoxidized soybean oil and styrene monomer. Food Additives and Contaminants, 24(2), 216-225. https://doi.org/10.1080/02652030600977833

Ehret-Henry, J., Ducruet, V., Luciani, A., \& Feigenbaum, A. (1994). Styrene and ethylbenzene migration from polystyrene into dairy products by dynamic purge-and-trap gas chromatography. J. Food Sci., 59(5), 990-992, 1001. https://doi.org/10.1111/j.1365-2621.1994.tb08174.x

FDA. (2007). Guidance for Industry: Preparation of Premarket Submissions for Food Contact Substances (Chemistry Recommendations). Docket Number: FDA-2013-S-0610. Issued by: Office of Foods and Veterinary Medicine, Center for Food Safety and Applied Nutrition. Retrieved from https://www.fda.gov/regulatory-information/search-fda-guidance-documents/guidance-industry-preparation -premarket-submissions-food-contact-substances-chemistry\#iid1d

Flanjak, J., \& Sharrad, J. (1984). Quantitative analysis of styrene monomer in foods: A limited East Australian survey. J. Sci. Food Agric., 35, 457-462. https://doi.org/10.1002/jsfa.2740350416

Gawell, B-M., \& Larsson, B. (1980). Determination of styrene in foods by reversed-phase high performance liquid chromatography. J. Chromatogr., 198, 198-202. https://doi.org/10.1016/S0021-9673(00)80110-7

Gelbke, H. P., Banton, M., Faes, E. R., Leibold, E., Pemberton, M., \& Duhayon, S. (2014). Derivation of safe health-based exposure limits for potential consumer exposure to styrene migrating into food from food containers. Food Chemical Toxicology, 64, 258-269. https://doi.org/10.1016/j.fct.2013.11.039

Gelbke, H. P., Banton, M., Block, C., Dawkins, G., Eisert, R., Leibold, E., Pemberton, M., Pujik, I. M., Sakoda, A., \& Yasukawa, A. (2019). Risk assessment for migration of styrene oligomers into food from polystyrene food containers. Food Chemical Toxicology, 124, 151-167. https://doi.org/10.1016/j.fct.2018.11.017

Genualdi, S., Nyman, P., \& Begley, T. (2013). Updated evaluation of the migration of styrene monomer and oligomers from polystyrene food contact materials to foods and food simulants. Food Additives and Contaminants, 31(4), 723-733. https://doi.org/10.1080/19440049.2013.878040

Gilbert, S. G. (1979). Modelling the migration of indirect additives to food. Food Tech., 33(4), 63-65.

Gilbert, J., \& Startin, J. R. (1981). Single-ion monitoring of styrene in foods by coupled mass spectrometry-headspace gas chromatography. J. Chromatogr., 205, 434-437. https://doi.org/10.1016/S0021-9673(00)82672-2

Gilbert, J., \& Startin, J. R. (1982). Determination of acrylonitrile monomer in food packaging materials and in foods. Food Chem., 9, 243-252. https://doi.org/10.1016/0308-8146(82)90075-9

Gilbert, J., \& Startin, J. R. (1983). A survey of styrene monomer levels in foods and plastic packaging by coupled mass spectrometry-automatic headspace gas chromatography. J. Sci. Food Agric., 34, 647-652. https://doi.org/10.1002/jsfa.2740340616

Harte, B. R., \& Gray, J. I. (1987). The influence of packaging on product quality. In J. I. Gray, B. R. Harte \& J. 
Miltz (Eds.), Food product-package compatibility (pp. 17-29). Technomic Publishing Inc., PA.

Health Canada. (1993). Canadian Environmental Protection Act. Priority Substances List. Assessment Report: Styrene. Cat. No.: En40-215/24F.

Hollifield, H. C., Breder, C. V., Dennison, J. L., Roach, J. A. G., \& Adams, W. S. (1980). Container-derived contamination of maple syrup with methymetacrylate, toluene and styrene as determined by headspace gas-liquid chromatography. J. AOAC., 63(2), 173-177. https://doi.org/10.1093/jaoac/63.2.173

Hollifield, H. C., Snyder, R. C., McNeal, T. P., \& Fazio, T. (1988). Recent advances in analytical methods for determination of migrants. In J. H. Hotchkiss (Ed.), Food and_Package interactions (pp. 137-145). ACS Series 365. https://doi.org/10.1021/bk-1988-0365.ch011

Jensen, F. (1972). Determination of monomers from polystyrene in milk products. Ann. Ist. Super. Sanita., 8, 443-448.

Jickells, S. M., Crews, C., Castle, L., \& Gilbert, J. (1990). Headspace analysis of benzene in food contact materials and its migration into foods from plastics cookware. Food Addit. Contam., 7(2), 197-205. https://doi.org/10.1080/02652039009373884

Jickells, S., Gancedo, P., Nerin, C., Castle, L., \& Gilbert, J. (1993). Migration of styrene monomer from thermoset polyester cookware into foods during high temperature applications. Food Addit. Contam., 10(5), 567-573. https://doi.org/10.1080/02652039309374179

Khaksar, M-R., \& Ghazi-Khansari, M. (2009). Determination of migration monomer styrene from GPS (general purpose polystyrene and HIPS (high impact polystyrene) cups to hot drinks. Toxicology Mechanisms and Methods, 19(3), 257-261. https://doi.org/10.1080/15376510802510299

Koros, W. J., \& Hopfenberg, H. B. (1979). Scientific aspects of migration of indirect additives from plastics to food. Food Tech., 4, 56-60.

Le Sech, J., Ducruet, V., \& Fiegenbaum, A. (1994). Influence of dissolved gases in the dynamic headspace analysis of styrene and other volatile organic compounds and improvement of their determination. $J$. Chromatogr. A, 667, 340-347. https://doi.org/10.1016/0021-9673(94)89086-2

Lickly, T. D., Markham, D. A., \& McDonald, M. E. (1993). Migration of acrylonitrile from styrene/acrylonitrile copolymers into food-simulating liquids. J. Agric. Food Chem., 41, 119-124. https://doi.org/10.1021/jf00025a026

Lickly, T. D., Breder, C. V., \& Rainey, M. L. (1995a). A model for estimating the daily dietary intake of a substance from food-contact articles: Styrene from polystyrene food-contact polymers. Reg. Toxicol. Pharma., 21, 406-417. https://doi.org/10.1006/rtph.1995.1055

Lickly, T.D., Lehr, K.M. \& Welsh, G.C. (1995b). Migration of styrene from polystyrene foam food-contact articles. Food Chem. and Toxicol., 33(6), 475-481. https://doi.org/10.1016/0278-6915(95)00009-Q

Lin, Q-B., Song, X-C., Fang, H., Wu, Y-M., \& Wang, Z-W. (2017). Migration of styrene and ethylbenzene from virgin and recycled expanded polystyrene containers and discrimination of these two kinds of polystyrene by principal component analysis. Food Addit. Contam., 34(1), 126-132.

https://doi.org/10.1080/19440049.2016.1253875

Linssen, J. P. H., Legger-Huysman, A., \& Roozen, J. P. (1990). Recognition threshold concentrations of migrants from food packages: Styrene and Ethylbenzene. In Y. Bessiere \& A. F Thomas (Eds.), Flavour Science and Technology (pp. 359-362). Wiley \& Sons, Inc., NY.

Linssen, J. P. H., Janssens, J. L. G. M., Reitsma, J. C. E., \& Roozen, J. P. (1991a). Sensory analysis of polystyrene packaging material taint in cocoa powder for drinks and chocolate flakes. Food Addit. Contam., 7(1), 1-7. https://doi.org/10.1080/02652039109373950

Linssen, J. P. H., Reitsma, J. C. E., \& Roozen, J. P. (1991b). Effect of sampling method on the level of styrene monomer migrated from polystyrene packages. Pack. Tech. Sci., 4, 171-175. https://doi.org/10.1002/pts.2770040309

Linssen, J. P. H., Janssens, A. L. G. M., Reitsma, H. C. E., Bredie, W. L. P., \& Roozen, J. P. (1993). Taste recognition threshold concentrations of styrene in oil-in-water emulsions and yoghurts. J. Sci. Food Agric., 61, 457-462. https://doi.org/10.1002/jsfa.2740610413

Loprieno, N., Abbondandolo, A., Barale, R., Baroncelli, S., Bonatti, S., Bronzetti, G., ... Rossi, A. M. (1976). 
Mutagenicity of industrial compound: Styrene and its possible metabolite styrene oxide. Mutat. Res., 40, 317-324. https://doi.org/10.1016/0165-1218(76)90030-6

Mannheim, C. H., Miltz, J., \& Letzter, A. (1987). Interaction between polyethylene-laminated cartons and aseptically packed citrus juices. J. Food Sci., 52(3), 77-740.

https://doi.org/10.1111/j.1365-2621.1987.tb06715.x

Mannheim, C. H., Miltz, J., \& Passy, N. (1988). Interaction between aseptically filled citrus products and laminated structures. In J. H. Hotchkiss (Ed.), Food and Package Interactions (pp. 68-82). ACS Series 365. https://doi.org/10.1021/bk-1988-0365.ch006

Meretoja, T., Vainio, H., Sorsa, M., \& Härkönen, H. (1977). Occupational styrene exposure and chromosomal aberrations. Mutat. Res., 56, 193-197. https://doi.org/10.1016/0027-5107(77)90209-3

Miltz, J. (1987). Migration of low molecular weight species from packaging materials: theorethical and practical considerations. In J. I. Gray, B. R. Harte \& J. Miltz (Eds.), Food product-package compatibility (pp. 30-43). Technomic Publishing, Inc. PA.

Miltz, J., Elisha, C., \& Mannheim, C. H. (1980). Sensory threshold of styrene monomer migration from polystyrene food packages. J. Food Proces Preserv., 4, 281-289. https://doi.org/10.1111/j.1745-4549.1980.tb00612.x

Miltz, J., \& Rosen-Doody, V. (1984). Migration of styrene monomer from polystyrene packaging materials into food simulants. J. Food Proces Preserv., 8, 151-161. https://doi.org/10.1111/j.1745-4549.1985.tb00694.x

Miltz, J., \& Mannheim, C. H. (1987). The effect of polyethylene contact surface on the shelf-life of food products. In J. I. Gray, B. R. Harte \& J. Miltz (Eds.), Food product-package compatibility (pp. 245-257). Technomic Publishing, Inc. PA.

Murphy, P. G., MacDonald, D. A., \& Lickly, T. D. (1992). Styrene migration from general- purpose and high-impact polystyrene into food-simulating solvents. Food. Chem. Toxic., 30(3), 225-232. https://doi.org/10.1016/0278-6915(92)90037-L

Nerin, C., Gancedo, P., \& Cacho, J. (1993). Determination of styrene in olive oil by coevaporation, cold trap, and GC/MS/SIM. J. Agric. Food Chem., 41, 2003-2005. https://doi.org/10.1021/jf00035a036

O’Neill, E. T., Tuohy, J. J., \& Franz, R. (1994). Comparison of milk and ethanol/water mixtures with respect to monostyrene migration from a polystyrene packaging material. Int. Dairy Journal, 4, 271-283. https://doi.org/10.1016/0958-6946(94)90017-5

Paraskevopoulou, D., Achilias, D. S., \& Paraskevopoulou, A. (2011). Migration of styrene from plastic packaging based on polystyrene into food simulants. Polymer International, 61(1), 141-148. https://doi.org/10.1002/pi.3161

Philo, M. R., Jickells, S. M., Damant, A. P., \& Castle, L. (1994). Stability of plastic monomers in food-simulating liquids under European Union migration test conditions. J. Agric. Food Chem., 42, 1497-1501. https://doi.org/10.1021/jf00043a020

Pugh, S. R. (1994). Modelling chemical migration from packaging into food. In D. H. Watson \& M. N. Meah (Eds.), Food Science Reviews: Chemical migration from food packaging (pp. 137-156). Ellis Horwood Limited, UK.

Reid, R. C., Sidman, K. R., Schwope, A. D., \& Till, D. E. (1980). Loss of adjuvants from polymer films to foods or food simulants. Effect of the external phase. Ind. Eng. Chem. Prod. Res. Dev., 19, 580-587. https://doi.org/10.1021/i360076a019

Sadler, G. (1993). Titratable acidity. In S. S. Nielsen (Ed.), Introduction to the chemical analysis of foods (pp. 81-92). Jones and Bartlett Publishers, MA.

Santa-Maria, I., Carmi, J. D., \& Ober, A. G. (1986). Residual styrene monomer in Chilean Foods by headspace gas chromatography. Bull. Environ. Contam. Toxicol., 37, 207-212. https://doi.org/10.1007/BF01607751

Schwartz, P. (1985). Regulatory requirements for new packaging materials and processing technologies. Food Tech., 39(12), 61-63.

Schwartz, P. (1987). Petitiononing for new packaging materials. In J. I. Gray, B. R. Harte \& J. Miltz (Eds.), Food product-package compatibility (p280-286). Technomic Publishing, Inc. PA.

Simmons, C. (2009). Guidelines on testing conditions for articles in contact with foodstuffs. CRL-NRL-FCM 
Publication 1st Edition. p. 20-21. Retrieved from https://publications.jrc.ec.europa.eu/repository/bitstream/JRC51601/guidelines\%20test\%20conditions_final _ed2009.pdf

Snyder, R. C., \& Breder, C. V. (1985). New FDA migration cell used to study migration of styrene from polystyrene into various solvents. J. AOAC., 68(4), 770-775. https://doi.org/10.1093/jaoac/68.4.770

Steichen, R. J. (1976). Modified solution approach for the gas chromatographic determination of residual monomers by headspace analysis. Anal. Chem., 48(9), 1398-1402. https://doi.org/10.1021/ac50003a032

Tawfik, M. S., \& Huyghebaert, A. (1997). Polystyrene cups and containers: Styrene migration. Food Additives and Contaminants, 15(5), 592-599. https://doi.org/10.1080/02652039809374686

Till, D. E., Ehntholt, D. J., Reid, R. C., Schwartz, P. S., Sidman, K. R., Schwope, A. D., \& Whelan, R. H. (1982a). Migration of BHT antioxidants from high density polyethylene to foods and food simulants. Ind. Eng. Chem. Prod. Res. Dev., 21, 106-113. https://doi.org/10.1021/i300005a023

Till, D. E., Ehntholt, D. J., Reid, R. C., Schwartz, P. S, Sidman, K. R., Schwope, A. D., \& Whelan, R. H. (1982b). Migration of styrene monomer from crystal polystyrene to foods and food simulating liquids. Ind. Eng. Chem. Prod. Res. Dev., 21, 161-168. https://doi.org/10.1021/i100006a010

Till, D. E., Schwope, A. D., Ehntholt, D. J., Sidman, K. R., Whelan, R. H., Schwartz, P. S., \& Reid, R. C. (1987). Indirect food additive migration from polymeric food packaging materials. CRC Critical Reviews in Toxicology, 18(3), 215-243. https://doi.org/10.3109/10408448709089862

Tressler, K. D., \& Woodroff, J. G. (1976). Food product formulary. The AVI publishing, Inc., CT. Volume 3, p. $1-31$.

US EPA. (1990). Integrated Risk Information System. Styrene. Retrieved from http://www.epa.gov/iris/

US FDA. (2007). United States Food and Drug Administration, Guidance for Industry: Preparation of premarket submission for food contact substances (Chemistry recommendations). Retrieved from https://www.fda.gov/regulatory-information/search-fda-guidance-documents/guidance-industry-preparation -premarket-submissions-food-contact-substances-chemistry\#iid1c

US FDA CFR. (2019). Code of Federal Regulations Title 21, Volume 3 revised as of April 1, 2019.21CFR177.1640. Chapter 1, subchapter B, part 177 -indirect food additives: polymers. Subpart B--Substances for Use as Basic Components of Single and Repeated Use Food Contact Surfaces Sec. 177.1640 Polystyrene and rubber-modified polystyrene. Retrieved from https://www.accessdata.fda.gov/scripts/cdrh/cfdocs/cfcfr/cfrsearch.cfm?fr=177.1640

Varner, S. L., \& Breder, C. H. (1981a). Liquid chromatographic determination of residual styrene in polystyrene food packaging. J. Assoc. Off. Anal. Chem., 64(3), 647-652. https://doi.org/10.1093/jaoac/64.3.647

Varner, S. L., \& Breder, C. H. (1981b). Headspace sampling and gas chromatographic determination of styrene migration from food-contact polystyrene cups into beverages and food simulants. J. Assoc. Off. Anal. Chem., 64(5), 1122-1130. https://doi.org/10.1093/jaoac/64.5.1122

Varner, S. L., Breder, C. H., \& Fazio, T. (1983). Determination of styrene migration from food-contact polymers into margarine, using azeotropic distillation and headspace chromatography. J. Assoc. Off. Anal. Chem., 66(5), 1067-1073. https://doi.org/10.1093/jaoac/66.5.1067

Withey, J. R., \& Collins, P. G. (1978). Styrene monomer in foods: A limited Canadian Survey., Bull. Environ. Contam. Toxicol., 19, 86-94. https://doi.org/10.1007/BF01685771

Withey, J. R. (1976). Quantitative analysis of styrene monomer in polystyrene and foods including some preliminary studies of the uptake and pharmacodynamics of the monomer in rats. Environmental Health Perspectives, 17, 125-133. https://doi.org/10.1289/ehp.7617125

WHO. (2003). Styrene in Drinking Water; Background Document for Development of WHO Guidelines for Drinking-water Quality. WHO/SDE/.

\section{Copyrights}

Copyright for this article is retained by the author(s), with first publication rights granted to the journal.

This is an open-access article distributed under the terms and conditions of the Creative Commons Attribution license (http://creativecommons.org/licenses/by/4.0/). 